\title{
Influences of breed, sex and age on seasonal changes in haematological variables of tropical goat kids
}

\author{
Buhari Habibu ${ }^{1}$, Mohammed Kawu ${ }^{1}$, Hussaina Makun ${ }^{2}$, Tagang Aluwong ${ }^{1}$, Lukman Yaqub ${ }^{1}$, \\ Tavershima Dzenda ${ }^{1}$, and Hajarah Buhari ${ }^{3}$ \\ ${ }^{1}$ Department of Veterinary Physiology, Ahmadu Bello University, Zaria, Nigeria \\ ${ }^{2}$ Small Ruminant Research Programme, National Animal Production Research Institute, Zaria, Nigeria \\ ${ }^{3}$ Samaru College of Agriculture, Division of Agricultural Colleges, Ahmadu Bello University, Zaria, Nigeria \\ Correspondence to: Buhari Habibu (buharihabibu@ rocketmail.com)
}

Received: 9 October 2016 - Revised: 2 March 2017 - Accepted: 7 March 2017 - Published: 31 March 2017

\begin{abstract}
The influences of breed, sex and age on seasonal changes in haematological variables of kids (14 months old) belonging to Red Sokoto $(n=60)$ and Sahel $(n=60)$ goats were studied at the peaks of the cold-dry, hot-dry and rainy seasons in a West Africa Guinea savanna climate. The results showed that, during the hot-dry season, Sahel goat kids had significantly higher $(P<0.05)$ packed cell volume (PCV) and red blood cell $(\mathrm{RBC})$ count but lower $(P<0.05)$ mean corpuscular volume $(\mathrm{MCV})$, mean corpuscular haemoglobin $(\mathrm{MCH})$, mean corpuscular haemoglobin concentration (MCHC) and total leucocyte count than Red Sokoto kids. Similarly, younger kids of both breed had significantly higher $(P<0.05)$ PCV and RBC but lower $\mathrm{MCV}, \mathrm{MCH}$ and MCHC compared with the older kids during the hot-dry season. Younger kids (1-2 months) of both breeds exhibited significantly $(P<0.05)$ high PCV and RBC but low MCH and MCHC during the hot-dry season as compared with the cold-dry and rainy seasons, with the magnitude of the change being greater in Sahel kids. More remarkable seasonal fluctuations in haematological parameters were observed in buck kids than doe kids of both breeds. Multivariate analysis revealed a clear distinction between the change in haematological parameters during the cold-dry as compared with the hot-dry and rainy seasons, with MCV having the strongest discriminating power $\left(0.91^{*}\right)$. In conclusion, breed, age and sex variations in haematological variables of goats were more pronounced in the hot-dry season, during which the seasonal changes were more dramatic in kids of Sahel goats, as well as in younger and male kids of both breeds. These findings may be useful in the management of tropical goat kids in different seasons.
\end{abstract}

\section{Introduction}

In many developing countries of the world, different breeds of goats play vital roles in the economy, religion, nutrition and tradition of poor livestock owners. In Nigeria, the three distinct indigenous breeds of goats are Red Sokoto (Maradi or Savanna Brown), Sahel (West African Long-legged or White Bornu) and West African Dwarf (Egwu et al., 1995). Distribution of the goat breeds indicates that the Red Sokoto goats are common in the Sudanian Savanna region of the Republic of Niger and the Guinea and Sudanian Savanna regions of Nigeria; the Sahel or desert goats are found in the Sahel belt of West Africa (Fig. 1), while the West African
Dwarf goats are largely restricted to the coast of West and Central Africa (Gall, 1996; Habibu et al., 2016a). In recent years, adaptation of these breeds of goats, particularly the Sahel goats, to new geographical regions of the country, including the northern Guinea savanna zone and rainforest zone has been observed (Habibu et al., 2017).

The Guinea savanna climate of West Africa is found north of the rainforest zone, while the Sahel climate is located south of the Sahara (Fig. 1). The northern Guinea savanna zone of Nigeria is a semi-arid region with three distinct seasons, namely the cold-dry (CDS), hot-dry (HDS) and rainy (RAS) seasons (Igono and Aliu, 1982; Dzenda et al., 2015). Like the young offspring of other livestock species, 

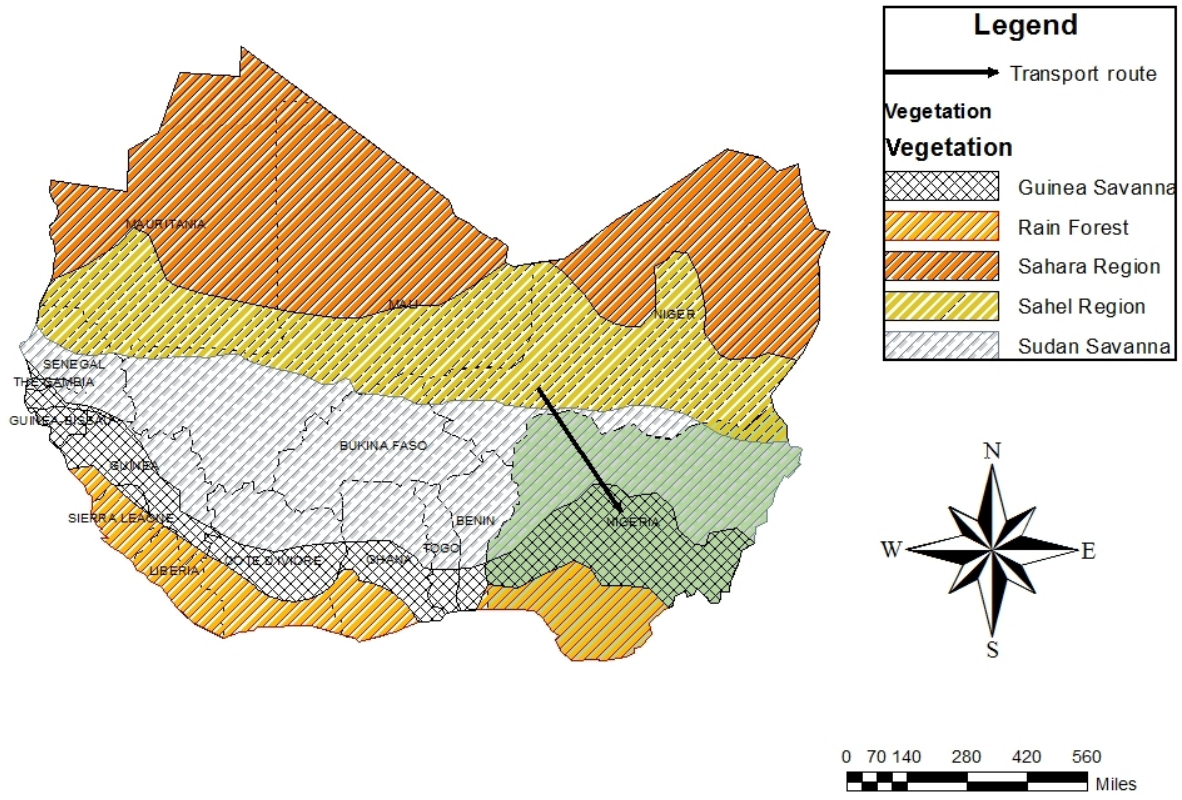

Figure 1. Map of West Africa indicating the geographical zones and transportation of Sahel goats. The map was carved and modified using a section of the map of Africa obtained from Bioclimatic Regions Map (https://eros.usgs.gov/westafrica/node/147) as a guide.

goat kids are confronted with the challenge of extra-uterine environment that is entirely different from that in the uterus, which makes them metabolically unstable and may increase their susceptibility to perinatal diseases, resulting in high neonatal mortality, most especially in thermally stressful seasons (Piccione et al., 2007). In West Africa, pre- and postweaning kid mortality has been reported to be as high as 10 and $23.1 \%$, respectively (Turkson et al., 2004). The newborns that survive usually adapt by developing functional changes in almost all organs and systems through a series of tissue-based metabolic and morphologic remodelling (Saddiqi et al., 2011), which greatly affects the survival of the newborn and, if effective, may reduce the incidence of newborn mortality (Nowak et al., 2000). The adaptive response of the newborn to the novel environments may differ due to differences in breed (Sawalha et al., 2007). Since most tropical breeds of goats are non-seasonal breeders, they cycle yearround and parturition may occur in any season of the year. Accordingly, kids may be exposed to all the distinct seasons of the year.

Like other tissues, the blood may undergo series of adaptive remodelling on exposure to the extra-uterine environment in different seasons. Haematological parameters are generally used to monitor and evaluate the health of small ruminants (Fazio et al., 2016). Due to the economic importance of goats, a lot of information is available on their haematology (Tibbo et al., 2004; Zumbo et al., 2011; Piccione et al., 2014). Breed, sex, age and season may greatly influence haematological profile of goats, with season classically increasing or decreasing haematological variables (EgbeNwiyi et al., 2000; Tibbo et al., 2004; Zumbo et al., 2011;
Habibu et al., 2017). However, there is a paucity of information on the haematological responses of different breeds, sexes and age groups of goat kids in different seasons of the tropics. Findings from the current study may provide valuable information on variations in physiological variables of tropical goats in relation to different endogenous and exogenous factors. Similarly, the study may provide information that could be useful in the management of goat kids in different seasons and in the design of a breeding programme to ensure parturition occurs in seasons that are less stressful. Therefore, the aim of the present study was to evaluate the influence of breed, sex and age on the seasonal changes in haematological variables of goat kids in the northern Guinea savanna zone of Nigeria.

\section{Materials and methods}

\subsection{Experimental site and animal management}

The study was carried out in the Small Ruminant Research Section of the National Animal Production Research Institute (NAPRI), Ahmadu Bello University, Shika, Zaria, Nigeria, located at $11^{\circ} 12^{\prime} \mathrm{N}, 7^{\circ} 33^{\prime} \mathrm{E}$ and an altitude of $610 \mathrm{~m}$ above sea level. The animals were housed in well-ventilated pens each with dimensions of $6.1,6.1$ and $2.2 \mathrm{~m}$ for length, width and height, respectively. The roofs of the pens were made of galvanized metal sheet, while the floor was covered with concrete. The pens had a stocking density of 35 kids. The health status of the goats was evaluated based on behaviour, rectal temperature $\left(38.00-39.76^{\circ} \mathrm{C}\right)$, respiratory rate (22-34 breaths per minute), heart rate (60.36- 
90.34 beats per minute), appetite and faecal consistency. Animals on the farm were routinely screened by a trained staff member for helminths (using floatation and sedimentation tests) and haemoparasites. Only clinically healthy animals were used for the study. Both breeds of goats were housed within the same environment during all the seasons. Adult Red Sokoto and Sahel does were oestrous-synchronized using CIDR and mated by proven Red Sokoto and Sahel bucks, respectively. Kids born from Red Sokoto and Sahel does that were homogeneous for age (4 to 5 years), live weight $(25 \pm 1.6 \mathrm{~kg})$ and body condition score $(2.9 \pm 0.1)$ were used for the study. Body condition was scored by the same person adopting a six-point scale method (Santucci et al., 1991). The kids were weaned at 2 months of age and provided with milk (by directly suckling their dams) and concentrate - ration of ground maize (30\%), cotton seed cake (36\%), maize offal $(20 \%)$, wheat offal (10\%), bone meal $(2.5 \%)$ and salt $(1.5 \%)$ at $3 \%$ body weight per day - depending on their age. Good-quality drinking water was provided ad libitum.

\subsection{Experimental design}

The goat kids were sampled at the peak of the CDS, HDS and RAS during the months of December, April and July, respectively. A total of 120 goat kids, aged between 1 and 4 months and with body weight ranging from 2 to $8 \mathrm{~kg}$, were used throughout the study period. In each season, 40 different sets of kids (20 kids from each of the two breeds) of both sexes were sampled as follows: Red Sokoto buck kids $(n=10)$, Red Sokoto doe kids $(n=10)$, Sahel buck kids $(n=10)$ and Sahel doe kids $(n=10)$. The kids from each breed were further divided into younger (1-2 months) and older (3-4 months) kids. The ratios of younger to older Red Sokoto kids were $11: 9,8: 12$ and $7: 13$ during the CDS, HDS and RAS, respectively, while those for Sahel kids were 10:10 (CDS), 9:11 (HDS) and 13:7 (RAS).

The study protocol and animal experimentation were reviewed and approved by the Animal Use and Welfare Committee of Ahmadu Bello University, Zaria, and the research followed the international guidelines for animal welfare.

\subsection{Blood sample collection and analysis}

Five millilitres $(5 \mathrm{~mL})$ of blood was obtained from each kid once in every season during the morning hours, between 08:00 and 10:00 (GMT+1), through the jugular vein into Vacutainer tubes containing potassium ethylenediaminetetra acetic acid ( $\mathrm{K}_{3}$ EDTA). The blood sample was transported to the laboratory in an ice pack and analysed an hour after collection. Counting of erythrocytes and leukocytes was done manually using a haemocytometer. Packed cell volume (PCV) was measured using the microhaematocrit method (Jain, 1986). The centrifugation time was increased $(3000 \times g$ for $15 \mathrm{~min})$ to ensure complete packing because of the small size of caprine erythrocytes. Haemoglobin $(\mathrm{Hb})$ concentration was determined using a haemoglobin meter (XF-1C haemoglobin meter, China). Only the counts of lymphocytes and neutrophils were determined, since the study was mainly aimed at evaluating the response of the kids to thermal stress. The mean corpuscular volume (MCV), mean corpuscular haemoglobin $(\mathrm{MCH})$ and mean corpuscular haemoglobin concentration (MCHC) were then derived using standard formulae (Jain, 1986).

\subsection{Meteorological parameters}

The morning (09:00-10:00 h) and afternoon (13:00-14:00 h) values of air temperature and relative humidity, as well as duration of sunshine $(\mathrm{h})$ and total rainfall $(\mathrm{mm})$, recorded daily during the week the study was conducted, were obtained from the Meteorological Unit, Institute for Agricultural Research, Ahmadu Bello University, Zaria, located about $5 \mathrm{~km}$ away from the experimental site. The values of the morning and afternoon temperature-humidity index (THI) were used to evaluate the level of heat stress induced by the environment. The formula reported by Ravagnolo et al. (2000) was used to calculate THI:

$$
\begin{aligned}
\mathrm{THI} & =(1.8 \times T+32)-\{(0.55-0.0055 \cdot \mathrm{RH}) \\
& \cdot(1.8 \times T-26)\},
\end{aligned}
$$

where $T$ is ambient temperature $\left({ }^{\circ} \mathrm{C}\right)$ and $\mathrm{RH}$ is relative humidity $(\%)$.

\subsection{Data analysis}

The Statistical Package for Social Sciences (SPSS) version 20 was used to analyse the data. Values obtained were expressed as mean ( \pm SEM). Comparisons between breeds, sexes and age groups were done using Student's $t$ test, while univariate one-way analysis of variance (ANOVA) followed by the Duncan multiple range test were used to compare values between the three seasons. Discriminant analysis was performed to identify variables with greater discriminatory power between the three seasons. This was followed by the discriminant analysis option of variable classification. Values of $P<0.05$ were considered significant.

\section{Results}

\subsection{Meteorological parameters}

Mean values of meteorological parameters for each season are presented in Table 1 . The peak minimum and maximum ambient temperatures were recorded during the HDS in the morning and afternoon, respectively, while the corresponding nadir values were obtained during the CDS. Values of relative humidity at both morning and afternoon hours were lowest during the CDS but highest in the RAS. Duration of sunshine was longest and shortest during the CDS and RAS, respectively. Rainfall was recorded only during the RAS. 
Table 1. Mean values of meteorological parameters during the study period.

\begin{tabular}{|c|c|c|c|c|c|c|c|c|}
\hline \multirow[t]{2}{*}{ Seasons } & \multicolumn{2}{|c|}{$\begin{array}{c}\text { Ambient temperature } \\
\left({ }^{\circ} \mathrm{C}\right)\end{array}$} & \multicolumn{2}{|c|}{$\begin{array}{l}\text { Relative humidity } \\
\qquad(\%)\end{array}$} & \multicolumn{2}{|c|}{$\begin{array}{l}\text { Temperature- } \\
\text { humidity index }\end{array}$} & \multirow[t]{2}{*}{$\begin{array}{l}\text { Sunshine } \\
\text { (h) }\end{array}$} & \multirow[t]{2}{*}{$\begin{array}{r}\text { Rainfall } \\
(\mathrm{mm})\end{array}$} \\
\hline & Morning & Afternoon & Morning & Afternoon & Morning & Afternoon & & \\
\hline Cold-dry & 16.53 & 32.32 & 20.26 & 15.65 & 59.44 & 73.66 & 8.58 & 0 \\
\hline Hot-dry & 22.26 & 38.11 & 31.56 & 20.70 & 72.19 & 84.15 & 6.71 & 0 \\
\hline Rainy & 20.03 & 30.87 & 85.19 & 70.87 & 70.85 & 82.01 & 6.16 & 334.9 \\
\hline
\end{tabular}

Source: Meteorological Unit, Institute for Agricultural Research, Ahmadu Bello University, Zaria.

Table 2. Effect of season on haematological parameters of Red Sokoto and Sahel buck kids.

\begin{tabular}{|c|c|c|c|c|c|c|}
\hline \multirow[t]{2}{*}{ Parameter } & \multicolumn{2}{|c|}{ Cold-dry season } & \multicolumn{2}{|c|}{ Hot-dry season } & \multicolumn{2}{|c|}{ Rainy season } \\
\hline & Red Sokoto & Sahel & Red Sokoto & Sahel & Red Sokoto & Sahel \\
\hline $\operatorname{PCV}(\%)$ & $33.00 \pm 2.29$ & $34.00 \pm 4.77^{b}$ & $40.58 \pm 3.89^{y}$ & $56.28 \pm 5.87^{\mathrm{a}, \mathrm{x}}$ & $30.16 \pm 2.4$ & $31.42 \pm 2.65^{b}$ \\
\hline $\mathrm{RBC}\left(10^{6} / \mathrm{muL}\right)$ & $11.47 \pm 0.63$ & $10.01 \pm 1.56^{\mathrm{b}}$ & $10.70 \pm 1.2^{\mathrm{y}}$ & $19.05 \pm 0.24^{\mathrm{a}, \mathrm{x}}$ & $7.43 \pm 0.87$ & $7.73 \pm 0.66^{\mathrm{b}}$ \\
\hline $\mathrm{Hb}(\mathrm{g} / \mathrm{dL})$ & $10.00 \pm 0.23$ & $9.25 \pm 1.35$ & $10.00 \pm 0.23$ & $10.58 \pm 0.38$ & $9.48 \pm 0.26$ & $9.51 \pm 0.48$ \\
\hline MCV (fL) & $20.96 \pm 0.20$ & $20.74 \pm 0.16$ & $20.92 \pm 0.52$ & $20.28 \pm 0.33$ & $22.88 \pm 0.49$ & $21.56 \pm 0.67$ \\
\hline $\mathrm{MCH}(\mathrm{pg})$ & $6.63 \pm 0.06$ & $6.61 \pm 0.05^{\mathrm{b}}$ & $5.98 \pm 0.31^{\mathrm{a}, \mathrm{y}}$ & $3.32 \pm 0.33^{\mathrm{a}, \mathrm{x}}$ & $7.38 \pm 0.39^{b}$ & $6.72 \pm 0.30^{\mathrm{b}}$ \\
\hline $\mathrm{MCHC}(\mathrm{g} / \mathrm{dL})$ & $33.12 \pm 0.22$ & $33.29 \pm 0.03^{b}$ & $26.60 \pm 2.31^{y}$ & $16.61 \pm 1.66^{\mathrm{a}, \mathrm{x}}$ & $33.62 \pm 1.89$ & $31.47 \pm 1.72^{b}$ \\
\hline $\operatorname{TLC}\left(10^{3} / \mu \mathrm{L}\right)$ & $14.81 \pm 0.68$ & $13.41 \pm 1.83$ & $15.28 \pm 0.90^{\mathrm{y}}$ & $11.15 \pm 0.70^{\mathrm{x}}$ & $16.01 \pm 1.55$ & $13.08 \pm 0.90$ \\
\hline LYMP (\%) & $59.54 \pm 2.30$ & $65.98 \pm 3.21$ & $67.10 \pm 3.26^{\mathrm{a}}$ & $62.24 \pm 2.27$ & $54.36 \pm 2.06^{\mathrm{b}}$ & $59.17 \pm 2.98$ \\
\hline NEUT (\%) & $40.46 \pm 2.30$ & $34.02 \pm 3.21$ & $32.90 \pm 3.26$ & $37.76 \pm 2.27$ & $45.64 \pm 2.06$ & $40.83 \pm 2.98$ \\
\hline $\mathrm{N}: \mathrm{L}$ & $0.74 \pm 0.072$ & $0.70 \pm 0.18$ & $0.53 \pm 0.066$ & $0.53 \pm 0.11$ & $0.86 \pm 0.079$ & $0.73 \pm 0.09$ \\
\hline
\end{tabular}

Mean values of the same parameter with superscripts ${ }^{\mathrm{a}, \mathrm{b}}$ (within breed, but between seasons) and ${ }^{\mathrm{x}, \mathrm{y}}$ (between breeds and within season) are significantly different $(P<0.05)$. PCV, packed cell volume; RBC, red blood count; Hb, haemoglobin concentration; MCV, mean corpuscular volume; $\mathrm{MCH}$, mean corpuscular haemoglobin; MCHC, mean corpuscular haemoglobin concentration; TLC, total leucocyte count; LYMP, lymphocyte count (\%); NEUT, neutrophil count (\%);

$\mathrm{N}$ : L, neutrophil-lymphocyte ratio.

\subsection{Erythrocytic parameters}

Results on the effect of season on haematological variables of buck kids, doe kids and both sexes are presented in Table 2, 3 and 4 respectively, while the effect of season on haematological variables in different age groups of Red Sokoto and Sahel goat kids are presented in Tables 5 and 6, respectively. Irrespective of sex, significantly higher $(P<0.05) \mathrm{PCV}$ and RBC but lower MCH and MCHC were observed in Sahel than Red Sokoto kids during the HDS. Similarly, during the HDS, the Sahel goats had significantly higher $(P<0.05)$ $\mathrm{PCV}$ and RBC but lower MCH and MCHC compared with the CDS and RAS, with the changes being consistent irrespective of the sex. In Red Sokoto goats, however, the MCHC was significantly lower $(P<0.05)$ during the HDS as compared with the CDS and RAS (Table 4), while the RBC was significantly higher during the CDS compared with the RAS in doe kids. Values of MCV in both breeds were significantly lower in the HDS compared to the other seasons, with the value in Sahel goats being remarkably lower $(P<0.05)$ than that in Red Sokoto kids (Table 4). There was no significant breed difference $(P>0.05)$ in erythrocytic variables during the CDS and RAS.
Although no sex difference in haematological parameters of both breeds was observed in any season, sex variation was observed in the pattern of haematological changes in different seasons. Except for the significantly lower RBC during the HDS in buck kids of Red Sokoto, haematological variables in different sexes of Red Sokoto kids were not affected by season. This was unlike the Sahel goats, in which the haematological parameters of buck kids were significantly $(P<0.05)$ influenced by seasonal changes than those of doe kids. In the buck kids, significantly $(P<0.05)$ higher PCV and $\mathrm{RBC}$ but lower $\mathrm{MCH}$ and $\mathrm{MCHC}$ were observed, while only $\mathrm{MCH}$ and $\mathrm{MCHC}$ were significantly $(P<0.05)$ lower during the HDS compared with the CDS and RAS.

In both breeds of goats, the increase in PCV and RBC and decrease in $\mathrm{MCH}$ and $\mathrm{MCHC}$ during the HDS were observed to be more marked $(P<0.05)$ in younger kids (Tables 5 and 6). During the HDS, younger Red Sokoto kids had significantly lower $(P<0.05) \mathrm{MCV}$ values compared to their older counterparts. Throughout the study, Hb did not differ significantly between seasons, sexes and breeds. 
Table 3. Effect of season on haematological parameters of Red Sokoto and Sahel doe kids.

\begin{tabular}{|c|c|c|c|c|c|c|}
\hline \multirow[t]{2}{*}{ Parameter } & \multicolumn{2}{|c|}{ Cold-dry season } & \multicolumn{2}{|c|}{ Hot-dry season } & \multicolumn{2}{|c|}{ Rainy season } \\
\hline & Red Sokoto & Sahel & Red Sokoto & Sahel & Red Sokoto & Sahel \\
\hline PCV $(\%)$ & $34.11 \pm 0.51$ & $38.33 \pm 3.84$ & $36.68 \pm 2.61^{y}$ & $55.80 \pm 8.48^{\mathrm{a}, \mathrm{x}}$ & $30.99 \pm 2.61$ & $36.38 \pm 2.22^{b}$ \\
\hline $\mathrm{RBC}\left(10^{6} / \mu \mathrm{L}\right)$ & $13.37 \pm 0.45^{\mathrm{a}}$ & $12.41 \pm 0.78$ & $9.56 \pm 1.02^{\mathrm{y}}$ & $15.59 \pm 2.52^{\mathrm{a}, \mathrm{x}}$ & $7.79 \pm 0.69^{b}$ & $9.53 \pm 0.57^{b}$ \\
\hline $\mathrm{Hb}(\mathrm{g} / \mathrm{dL})$ & $10.46 \pm 0.19$ & $9.94 \pm 0.54$ & $9.90 \pm 0.34$ & $9.80 \pm 0.34$ & $9.86 \pm 0.34$ & $10.69 \pm 0.31$ \\
\hline MCV (fL) & $20.35 \pm 0.39$ & $20.20 \pm 0.58$ & $21.20 \pm 0.50$ & $21.24 \pm 0.52$ & $21.34 \pm 0.80$ & $20.74 \pm 0.55$ \\
\hline $\mathrm{MCH}(\mathrm{pg})$ & $6.58 \pm 0.08$ & $6.50 \pm 0.13^{b}$ & $6.30 \pm 0.26^{\mathrm{y}}$ & $3.33 \pm 0.52^{\mathrm{a}, \mathrm{x}}$ & $6.94 \pm 0.35$ & $6.20 \pm 0.24^{b}$ \\
\hline $\mathrm{MCHC}(\mathrm{g} / \mathrm{dL})$ & $33.54 \pm 0.26$ & $33.77 \pm 0.32^{b}$ & $28.50 \pm 1.59^{y}$ & $15.82 \pm 1.97^{\mathrm{a}, \mathrm{x}}$ & $32.66 \pm 1.49$ & $30.10 \pm 1.47^{b}$ \\
\hline $\operatorname{TLC}\left(10^{3} / \mu \mathrm{L}\right)$ & $14.85 \pm 1.56$ & $14.74 \pm 1.47$ & $17.23 \pm 0.75^{y}$ & $11.15 \pm 1.46^{\mathrm{x}}$ & $17.40 \pm 1.39$ & $15.27 \pm 1.85$ \\
\hline LYMP (\%) & $60.35 \pm 2.10$ & $57.17 \pm 3.57$ & $61.98 \pm 2.26^{\mathrm{a}}$ & $59.99 \pm 3.61$ & $54.54 \pm 2.61^{\mathrm{b}}$ & $56.30 \pm 2.76$ \\
\hline NEUT (\%) & $39.65 \pm 2.10$ & $42.83 \pm 3.57$ & $38.02 \pm 2.26$ & $40.01 \pm 3.61$ & $45.45 \pm 2.61$ & $43.70 \pm 2.76$ \\
\hline $\mathrm{N}: \mathrm{L}$ & $0.85 \pm 0.079$ & $0.84 \pm 0.17$ & $0.68 \pm 0.056$ & $0.63 \pm 0.14$ & $0.86 \pm 0.098$ & $0.77 \pm 0.08$ \\
\hline
\end{tabular}

Mean values of the same parameter with superscripts ${ }^{\mathrm{a}, \mathrm{b}}$ (within breed, but between seasons) and ${ }^{\mathrm{x}, \mathrm{y}}$ (between breeds and within season) are significantly different $(P<0.05)$. PCV, packed cell volume; RBC, red blood count; $\mathrm{Hb}$, haemoglobin concentration; $\mathrm{MCV}$, mean corpuscular volume; $\mathrm{MCH}$, mean corpuscular haemoglobin; MCHC, mean corpuscular haemoglobin concentration; TLC, total leucocyte count; LYMP, lymphocyte count (\%); NEUT, neutrophil count (\%);

$\mathrm{N}: \mathrm{L}$, neutrophil-lymphocyte ratio.

Table 4. Overall effect of season on haematological parameters of male and female Red Sokoto and Sahel goat kids.

\begin{tabular}{|c|c|c|c|c|c|c|}
\hline \multirow[t]{2}{*}{ Parameters } & \multicolumn{2}{|c|}{ Cold-dry season } & \multicolumn{2}{|c|}{ Hot-dry season } & \multicolumn{2}{|c|}{ Rainy season } \\
\hline & Red Sokoto & Sahel & Red Sokoto & Sahel & Red Sokoto & Sahel \\
\hline $\operatorname{PCV}(\%)$ & $33.45 \pm 1.35$ & $36.17 \pm 3.06^{\mathrm{a}}$ & $38.18 \pm 2.18^{y}$ & $56.04 \pm 4.98^{\mathrm{x}, \mathrm{b}}$ & $30.57 \pm 1.62$ & $33.90 \pm 1.62^{\mathrm{a}}$ \\
\hline $\operatorname{RBC}\left(10^{6} / \mu \mathrm{L}\right)$ & $12.42 \pm 0.45^{\mathrm{a}}$ & $11.21 \pm 0.99^{\mathrm{a}}$ & $10.13 \pm 0.72^{\mathrm{y}}$ & $17.31 \pm 1.44^{\mathrm{x}, \mathrm{b}}$ & $7.61 \pm 0.48^{\mathrm{b}}$ & $8.63 \pm 0.48^{\mathrm{a}}$ \\
\hline $\mathrm{Hb}(\mathrm{g} / \mathrm{dL})$ & $10.23 \pm 0.29$ & $9.59 \pm 0.75$ & $9.95 \pm 0.20$ & $10.19 \pm 0.21$ & $9.67 \pm 0.21$ & $10.10 \pm 0.30$ \\
\hline MCV (fL) & $20.80 \pm 0.20$ & $20.50 \pm 0.28^{\mathrm{a}}$ & $21.10 \pm 0.28^{\mathrm{y}, \mathrm{b}}$ & $20.76 \pm 0.32^{\mathrm{x}, \mathrm{b}}$ & $22.14 \pm 0.48^{\mathrm{a}}$ & $21.14 \pm 0.34^{\mathrm{a}}$ \\
\hline $\mathrm{MCH}(\mathrm{pg})$ & $6.61 \pm 0.05$ & $6.56 \pm 0.06^{\mathrm{a}}$ & $6.19 \pm 0.19^{y, b}$ & $3.33 \pm 0.28^{\mathrm{x}, \mathrm{b}}$ & $7.61 \pm 0.31^{\mathrm{a}}$ & $6.46 \pm 0.20^{\mathrm{a}}$ \\
\hline $\mathrm{MCHC}(\mathrm{g} / \mathrm{dL})$ & $33.33 \pm 0.17^{\mathrm{a}}$ & $33.53 \pm 0.16^{\mathrm{a}}$ & $27.55 \pm 1.30^{x, b}$ & $16.22 \pm 1.23^{\mathrm{x}, \mathrm{b}}$ & $33.14 \pm 1.19^{\mathrm{a}}$ & $30.78 \pm 1.57^{\mathrm{a}}$ \\
\hline $\operatorname{TLC}\left(10^{3} / \mu \mathrm{L}\right)$ & $14.83 \pm 0.76$ & $14.08 \pm 1.15$ & $16.26 \pm 0.48^{y}$ & $11.15 \pm 0.75^{\mathrm{x}}$ & $16.71 \pm 0.97$ & $14.18 \pm 1.02$ \\
\hline $\operatorname{LYMP}(\%)$ & $59.95 \pm 1.54$ & $61.58 \pm 3.70$ & $64.54 \pm 1.73^{b}$ & $61.11 \pm 3.01$ & $54.45 \pm 1.67^{\mathrm{a}}$ & $57.74 \pm 2.05$ \\
\hline $\operatorname{NEUT}(\%)$ & $40.05 \pm 1.54$ & $38.43 \pm 3.70$ & $35.46 \pm 1.73$ & $38.89 \pm 3.01$ & $45.55 \pm 1.67$ & $42.26 \pm 2.04$ \\
\hline $\mathrm{N}: \mathrm{L}$ & $0.80 \pm 0.079$ & $0.77 \pm 0.097$ & $0.61 \pm 0.045$ & $0.58 \pm 0.093$ & $0.86 \pm 0.055$ & $0.75 \pm 0.059$ \\
\hline
\end{tabular}

Mean values of the same parameter with superscripts ${ }^{\mathrm{a}, \mathrm{b}}$ (within breed, but between seasons) and ${ }^{\mathrm{x}, \mathrm{y}}$ (between breeds and within season) are significantly different $(P<0.05)$. PCV, packed cell volume; RBC, red blood count; Hb, haemoglobin concentration; MCV, mean corpuscular volume; MCH, mean corpuscular haemoglobin; MCHC, mean corpuscular haemoglobin concentration; TLC, total leucocyte count; LYMP, lymphocyte count (\%); NEUT, neutrophil count (\%);

$\mathrm{N}$ : L, neutrophil-lymphocyte ratio.

\subsection{Leucocytic parameters}

During the HDS, values of TLC in both sexes of Sahel goats were significantly lower $(P<0.05)$ than those in Red Sokoto kids. The percentage lymphocyte count (LYMP) was significantly $(P<0.05)$ lower during the RAS in comparison to the HDS in both sexes of Red Sokoto kids. The Red Sokoto buck kids had higher $(P<0.05)$ LYMP but lower $(P<0.05)$ percentage neutrophil counts (NEUT) than their female counterparts. Older Red Sokoto kids had significantly lower NEUT in the HDS compared with values recorded in the RAS. No significant difference $(P>0.05)$ was observed in neutrophillymphocyte ratio $(\mathrm{N}: \mathrm{L})$ among groups in the different seasons. The decrease in TLC during the HDS in Sahel goats was not significant $(P>0.05)$ when compared with the other seasons.

\subsection{Discriminant analysis}

Results on the discriminating powers of the variables are presented in Table 7. The variable with the greatest seasonal discriminating power was $\mathrm{MCV}$, followed by $\mathrm{MCHC}, \mathrm{MCH}$, $\mathrm{PCV}$ and RBC. Both the clusters formed in the canonical plot representation (Fig. 2) and classification of goats into their predicted group membership (Table 8) showed distinct separation in haematological variables between the CDS and the other two seasons, and close similarity in haematological variables between the HDS and RAS. The classification error was relatively low, while $89.7 \%$ of the kids were correctly classified into their respective groups. The only misclassification observed was between HDS and RAS. 
Table 5. Effect of season on haematological parameters of younger (1-2 months) and older (3-4 months) Red Sokoto goat kids.

\begin{tabular}{|c|c|c|c|c|c|c|}
\hline & \multicolumn{2}{|c|}{ Cold-dry season } & \multicolumn{2}{|c|}{ Hot-dry season } & \multicolumn{2}{|c|}{ Rainy season } \\
\hline & Young & Old & Young & Old & Young & Old \\
\hline$N$ & 10 & 10 & 9 & 11 & 13 & 7 \\
\hline $\operatorname{PCV}(\%)$ & $31.00 \pm 1.67$ & $33.00 \pm 1.55$ & $54.54 \pm 3.24^{\mathrm{a}, \mathrm{y}}$ & $34.9 \pm 2.66^{\mathrm{x}}$ & $31.23 \pm 2.86^{\mathrm{b}}$ & $28.83 \pm 2.48$ \\
\hline $\operatorname{RBC}\left(10^{6} / \mu \mathrm{L}\right)$ & $11.45 \pm 0.84$ & $12.89 \pm 1.08^{\mathrm{a}}$ & $16.16 \pm 0.78^{\mathrm{a}, \mathrm{x}}$ & $9.08 \pm 0.78^{\mathrm{y}}$ & $7.07 \pm 0.63^{\mathrm{b}}$ & $8.19 \pm 0.81^{b}$ \\
\hline $\mathrm{Hb}(\mathrm{g} / \mathrm{dL})$ & $9.22 \pm 0.61$ & $10.17 \pm 0.56$ & $9.93 \pm 0.33$ & $9.27 \pm 0.42$ & $9.58 \pm 0.50$ & $9.87 \pm 0.25$ \\
\hline MCV (fL) & $20.94 \pm 0.16$ & $21.20 \pm 0.25$ & $19.08 \pm 0.74^{\mathrm{x}, \mathrm{a}}$ & $21.98 \pm 0.26^{\mathrm{y}}$ & $23.12 \pm 0.49^{b}$ & $21.58 \pm 0.73$ \\
\hline $\mathrm{MCH}(\mathrm{pg})$ & $6.58 \pm 0.08^{\mathrm{b}}$ & $6.60 \pm 0.17$ & $3.38 \pm 0.27^{\mathrm{a}, \mathrm{x}}$ & $6.24 \pm 0.40^{\mathrm{y}}$ & $7.54 \pm 0.22^{\mathrm{b}}$ & $7.52 \pm 0.42$ \\
\hline $\mathrm{MCHC}(\mathrm{g} / \mathrm{dL})$ & $32.36 \pm 0.43^{b}$ & $33.82 \pm 0.43$ & $17.94 \pm 1.82^{\mathrm{a}, \mathrm{x}}$ & $29.09 \pm 1.58^{y}$ & $32.78 \pm 2.12^{\mathrm{b}}$ & $33.61 \pm 1.62$ \\
\hline $\operatorname{TLC}\left(10^{3} / \mu \mathrm{L}\right)$ & $13.86 \pm 1.87$ & $12.73 \pm 1.85$ & $14.72 \pm 1.23$ & $15.58 \pm 069$ & $18.65 \pm 1.68$ & $16.80 \pm 1.27$ \\
\hline $\operatorname{LYMP}(\%)$ & $67.23 \pm 1.83$ & $60.10 \pm 3.13$ & $64.60 \pm 3.52$ & $59.39 \pm 4.47$ & $53.64 \pm 3.81$ & $54.88 \pm 1.50$ \\
\hline NEUT $(\%)$ & $32.87 \pm 1.83$ & $39.90 \pm 3.13$ & $33.40 \pm 3.52$ & $37.86 \pm 2.33^{\mathrm{a}}$ & $46.36 \pm 3.81$ & $46.22 \pm 1.50^{b}$ \\
\hline $\mathrm{N}: \mathrm{L}$ & $0.51 \pm 0.53$ & $0.70 \pm 0.07$ & $0.60 \pm 0.06$ & $0.67 \pm 0.05$ & $0.67 \pm 0.05$ & $0.88 \pm 0.04$ \\
\hline
\end{tabular}

Mean values of the same parameter with superscripts $\mathrm{a}, \mathrm{b}$ (between seasons) and ${ }^{\mathrm{x}, \mathrm{y}}$ (within season) are significantly different $(P<0.05$ ). $N$, sample size; PCV, packed cell volume; RBC, red blood count; $\mathrm{Hb}$, haemoglobin concentration; $\mathrm{MCV}$, mean corpuscular volume; $\mathrm{MCH}$, mean corpuscular haemoglobin; $\mathrm{MCHC}$, mean corpuscular haemoglobin concentration; TLC, total leucocyte count; LYMP, lymphocyte count (\%); NEUT, neutrophil count (\%); N : L, neutrophil-lymphocyte ratio.

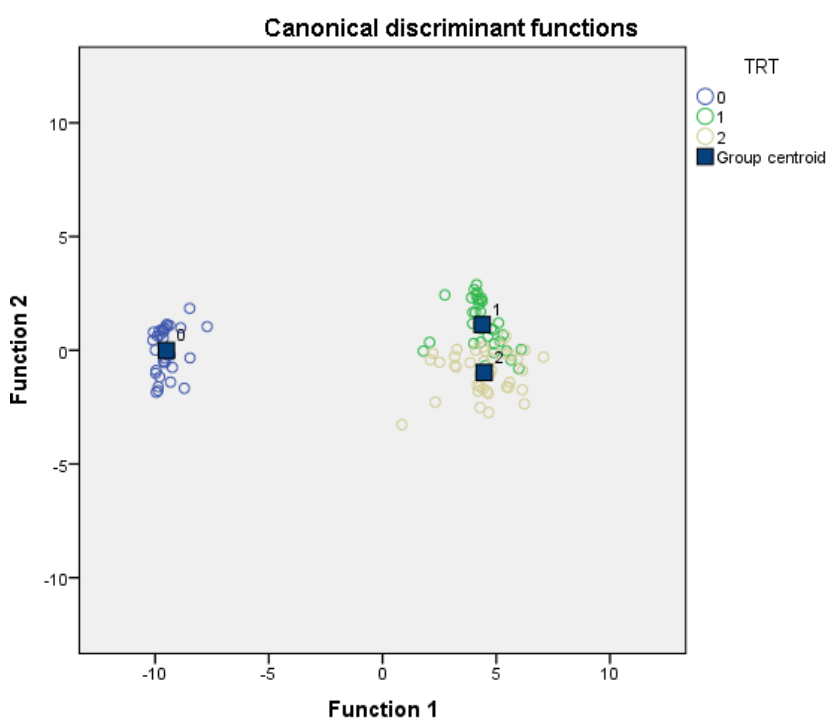

Figure 2. Canonical discriminant functions for the three seasons: 0 , CDS; 1, HSD; and 2, RAS.

\section{Discussion}

In comparison to the thermoneutral zone for goats (THI: 6575; Hamzaoiu et al., 2013), the kids were exposed to cold stress during the morning hours of the CDS (THI: 59.44) and heat stress during the afternoon hours of the HDS (THI: 84.15) and RAS (THI: 82.01). Generally, the haematological parameters recorded in the present study were within the normal range for goats reported by other authors (Jain, 1986; Addass et al., 2010; Zumbo et al., 2011), except for some deviations observed in PCV, RBC, MHC and MCHC during the HDS, particularly in the Sahel goat kids.
The high PCV and RBC recorded during the HDS of the current study, particularly in the Sahel and younger kids, agreed with the findings of previous studies (Sejian et al., 2013; Hashem, 2014). Severe dehydration has been reported in livestock exposed to thermal stress, which ultimately led to an increase in PCV, RBC and $\mathrm{Hb}$ (McManus et al., 2009; Sejian et al., 2014; Habibu et al., 2017). Thus, heat stress during the HDS was likely responsible for the high PCV and RBC observed in the current study, apparently due to increased thermoregulatory loss of body fluids. In contrast, other studies reported a decrease in PCV, $\mathrm{RBC}$ and $\mathrm{Hb}$ during heat stress, which was believed to be provoked by compensatory excess water intake (Mazzullo et al., 2014; Singh et al., 2016).

Since the increase in PCV during the HDS of the present study was not accompanied by a corresponding increase in $\mathrm{Hb}$, decreases in haemoglobin content $(\mathrm{MCH})$ and the cellular concentration (MCHC) were observed. The decrease in $\mathrm{MCH}$ and $\mathrm{MCHC}$ during the HDS affected both breeds, but with a more than $50 \%$ decrease in Sahel kids during this season compared with the other seasons. Several studies have reported a decrease in blood $\mathrm{Hb}$ parameters during the hot season or amid experimental heat exposure. For instance, $\mathrm{MCH}$ in goats (Abdelatif et al., 2009) and MCHC in Saanen goat kids (Temizel et al., 2009) and Niamey sheep (Al-Haidary, 2004) were reported to decrease due to high environmental temperature. Oxidative stress due to high ambient temperature may denature and precipitate haemoglobin molecules in the erythrocytes followed by their degradation (Pacifici et al., 1993; Giulivi et al., 1994), contributing to the low MCH and MCHC, particularly in the younger kids and kids of Sahel goats. The significantly low $\mathrm{MCH}$ and $\mathrm{MCHC}$ may also be indicative of low nutritional status as feed intake has been reported to decrease during heat stress (Srikandakumar et al., 
Table 6. Effect of season on haematological parameters of younger (1-2 months) and older (3-4 months) Sahel goat kids.

\begin{tabular}{|c|c|c|c|c|c|c|}
\hline & \multicolumn{2}{|c|}{ Cold-dry season } & \multicolumn{2}{|c|}{ Hot-dry season } & \multicolumn{2}{|c|}{ Rainy season } \\
\hline & Young & Old & Young & Old & Young & Old \\
\hline$N$ & 11 & 9 & 8 & 12 & 7 & 13 \\
\hline $\operatorname{PCV}(\%)$ & $42.33 \pm 7.21^{b}$ & $30.33 \pm 6.47$ & $59.53 \pm 3.90^{\mathrm{a}, \mathrm{y}}$ & $30.97 \pm 4.66^{\mathrm{x}}$ & $32.30 \pm 3.02^{b}$ & $36.66 \pm 2.45$ \\
\hline $\mathrm{RBC}\left(10^{6} / \mu \mathrm{L}\right)$ & $13.11 \pm 1.05^{\mathrm{b}}$ & $12.10 \pm 2.76$ & $19.19 \pm 0.96^{\mathrm{b}, \mathrm{x}}$ & $7.25 \pm 1.38^{y}$ & $8.19 \pm 0.81^{\mathrm{a}}$ & $9.56 \pm 0.60$ \\
\hline $\mathrm{Hb}(\mathrm{g} / \mathrm{dL})$ & $11.00 \pm 1.15$ & $9.60 \pm 2.11$ & $10.14 \pm 0.29$ & $9.30 \pm 0.78$ & $9.76 \pm 0.46$ & $10.79 \pm 0.32$ \\
\hline MCV (fL) & $20.86 \pm 0.05$ & $20.82 \pm 0.01$ & $20.22 \pm 0.29$ & $22.66 \pm 0.85$ & $21.62 \pm 0.84$ & $26.78 \pm 0.55$ \\
\hline $\mathrm{MCH}(\mathrm{pg})$ & $6.55 \pm 0.01^{\mathrm{b}}$ & $6.44 \pm 0.20$ & $3.31 \pm 0.24^{\mathrm{a}, \mathrm{x}}$ & $6.99 \pm 0.75^{\mathrm{y}}$ & $6.71 \pm 0.35^{\mathrm{b}}$ & $6.24 \pm 0.25$ \\
\hline MCHC (g/dL) & $33.24 \pm 0.02^{\mathrm{b}}$ & $33.95 \pm 0.62$ & $16.56 \pm 1.21^{\mathrm{a}, \mathrm{x}}$ & $30.83 \pm 2.83^{b}$ & $31.34 \pm 2.08^{\mathrm{b}}$ & $30.23 \pm 1.64$ \\
\hline $\operatorname{TLC}\left(10^{3} / \mu \mathrm{L}\right)$ & $11.79 \pm 2.13$ & $12.38 \pm 1.95$ & $14.14 \pm 0.29$ & $15.30 \pm 0.78$ & $13.85 \pm 0.93$ & $10.98 \pm 0.91$ \\
\hline LYMP (\%) & $61.99 \pm 6.66$ & $59.23 \pm 4.70$ & $64.33 \pm 3.12$ & $54.90 \pm 2.98$ & $58.27 \pm 3.08$ & $55.03 \pm 2.91$ \\
\hline $\operatorname{NEUT}(\%)$ & $36.01 \pm 6.66$ & $41.38 \pm 4.70$ & $35.67 \pm 3.12$ & $45.10 \pm 2.98$ & $41.73 \pm 3.08$ & $44.97 \pm 2.91$ \\
\hline $\mathrm{N}: \mathrm{L}$ & $0.61 \pm 0.19$ & $0.67 \pm 0.17$ & $0.47 \pm 0.08$ & $0.84 \pm 0.01$ & $0.75 \pm 0.10$ & $0.80 \pm 0.08$ \\
\hline
\end{tabular}

Mean values of the same parameter with superscripts ${ }^{\mathrm{a}, \mathrm{b}}$ (between seasons) and ${ }^{\mathrm{x}, \mathrm{y}}$ (within season) are significantly different $(P<0.05)$. $N$, sample size; PCV, packed cell volume; RBC, red blood count; Hb, haemoglobin concentration; $\mathrm{MCV}$, mean corpuscular volume; $\mathrm{MCH}$, mean corpuscular haemoglobin; MCHC, mean corpuscular haemoglobin concentration; TLC, total leucocyte count; LYMP, lymphocyte count (\%); NEUT, neutrophil count (\%);

$\mathrm{N}: \mathrm{L}$, neutrophil-lymphocyte ratio.

Table 7. Structural matrix with discriminant function for the three seasons.

\begin{tabular}{lrr}
\hline Variables & \multicolumn{2}{c}{ Functions } \\
\cline { 2 - 3 } & 1 & 2 \\
\hline MCV & $0.913^{*}$ & -0.143 \\
TLC & $0.167^{*}$ & -0.132 \\
MCHC & -0.065 & $-0.671^{*}$ \\
MCH & 0.309 & $-0.640^{*}$ \\
PCV & 0.026 & $0.591^{*}$ \\
RBC & -0.053 & $0.524^{*}$ \\
LYMP & 0.014 & $0.373^{*}$ \\
$\mathrm{~N}:$ L & -0.020 & $-0.359^{*}$ \\
NEUT & -0.006 & $-0.266^{*}$ \\
Hb & 0.006 & $-0.117^{*}$ \\
\hline
\end{tabular}

Asterisks $(*)$ indicate functions with significant loading. PCV, packed cell volume; $\mathrm{RBC}$, red blood count; $\mathrm{Hb}$, haemoglobin concentration; $\mathrm{MCV}$, mean corpuscular volume; $\mathrm{MCH}$, mean corpuscular haemoglobin; MCHC, mean corpuscular haemoglobin concentration; TLC, total leucocyte count; LYMP, lymphocyte count (\%); NEUT, neutrophil count (\%); $\mathrm{N}: \mathrm{L}$, neutrophil-lymphocyte ratio.

2003; Sejian et al., 2014). Although there was a decrease in $\mathrm{MCV}, \mathrm{MCH}$ and $\mathrm{MCHC}$ during the HDS in the current study, this may not be due to iron deficiency, since the $\mathrm{Hb}$ during the HDS was within the normal range for goats (Byers and Kramer, 2010) and comparable to other seasons.

In the current study, the values of MCV decreased during the HDS in comparison to the CDS and RAS, particularly in Sahel goats, and also showed the strongest discriminating power in distinguishing the kids based on the prevailing season. The finding agreed with those of Ribeiro et al. (2015)
Table 8. Percentage of kids classified into the three seasons.

\begin{tabular}{lrrr}
\hline Seasons & CDS & HDS & RAS \\
\hline Cold-dry & 40 & 0 & 0 \\
Hot-dry & 0 & 32 & 8 \\
Rainy & 0 & 4 & 36 \\
Error $(\%)$ & 0 & 10.3 & 20.6 \\
\hline
\end{tabular}

in Brazilian Azul goats and Mazzullo et al. (2014) in cattle, who also reported a decrease in MCV in animals exposed to natural heat stress. However, the finding disagreed with that of Abdelatif et al. (2009), who reported higher MCV values in Nubian goats of Sudan during summer than in winter. The decrease in MCV (average size of the erythrocytes) during the HDS may be due to an increase in the number of erythrocyte membrane vesicles formed and shed from the erythrocytes as a result of elevation in body temperature, with a resultant decrease in the size of the parent erythrocytes (Foller et al., 2010; Moore et al., 2013; Habibu et al., 2017). Thus, it is logical to infer that a decrease in MCV may have the potential of being used as an indicator of heat stress in tropical goats naturally exposed to heat stress.

The dramatic change in some haematological parameters of the younger goat kids compared to the relatively stable parameters in older kids observed during the HDS in the current study indicates that the former were more susceptible to heat stress than the latter. The finding agrees with that of Haque et al. (2013), in which the effect of thermal stress was higher in young buffalos, with an alteration in TLC of young buffalos, while the value was stable in the adults.

Previous studies in tropical (Banerjee et al., 2015; Singh et al., 2016) and arid (Srikandakumar et al., 2003) climates demonstrated diverse physiological responses of different 
breeds of goats and sheep to changes in meteorological parameters with some breeds showing better thermoregulation then others. Similarly, results of the current study revealed remarkable influence of breed in the seasonal changes in erythrocytic variables in both sexes. The kids of Red Sokoto goats apparently employed more efficient adaptive and survival strategies than Sahel goat kids, particularly during the HDS, which prevented the dramatic change in haematological parameters that was observed in Sahel goats. The higher magnitude of the increase in PCV and RBC in Sahel compared with Red Sokoto kids during the HDS may imply higher thermoregulatory fluid loss in Sahel kids, probably due to higher respiratory rate (Habibu et al., 2016b). This difference in breed response may be due to variation in thermoregulatory plasma fluid dynamics, as higher plasma volume, indicated by decrease in RBC and $\mathrm{Hb}$ has been reported in adult bucks of Red Sokoto, while an increase in PCV and RBC was observed in Sahel goats during the HDS when compared with CDS and RAS (Habibu et al., 2017). The ability of Red Sokoto goats to maintain relatively higher plasma volume, despite the expected thermoregulatory fluid loss during heat stress, indicates a higher level of adaptation to the tropical savanna and may, at least in part, explain why they naturally survive in diverse geographic locations (Sudan and Guinea savannas) and are the predominant breed of goats in Nigeria. The relatively stable haematological response demonstrated by Red Sokoto goats in the current study was probably because the breed is indigenous to the northern Guinea savanna region of Nigeria. This is unlike the Sahel goats, which are indigenous to the Sahel region of West Africa. Both regions have high ambient temperatures, but the Sahel region has a lower relative humidity due to its closeness to the Sahara (Fig. 1; Nicholson, 1995). Although a previous study reported higher erythrocyte membrane integrity in Sahel than Red Sokoto kids during the HDS (Habibu et al., 2016a), the higher relative humidity in the Guinea savanna of Nigeria may be a negative factor influencing thermoregulation of Sahel kids in the geographical area and may be responsible for the changes observed in erythrocytic parameters observed during the HDS (Habibu et al., 2017).

The current study revealed a remarkable influence of sex on the seasonal changes in erythrocytic variables in both breeds. The seasonal fluctuations in erythrocytic variables were better profound in buck kids than doe kids of both breeds, suggesting that the latter adapted more to the prevailing ambient conditions. Similarly, a previous study reported greater hazard during all postnatal periods in male compared with female lambs (Sawalha et al., 2007). In addition to other factors, a relatively poor homeostasis in the buck kids may, at least in part, contribute to the low survival rate generally reported in males compared with females among various breeds of goat kids (Awemu et al., 1999; ElAbid and Abu Nikhaila, 2009) and lambs (Turkson and Sualisu, 2005). Although more studies are needed to substantiate this hypothesis, these corroborative findings may imply that the female newborns of small ruminants have more efficient mechanisms of responding to postnatal challenges than their male counterparts.

The low TLC in Sahel as compared with Red Sokoto kids during the HDS in the current study supports the findings of Haldar (2012), who reported a decrease in TLC in goats exposed to heat stress. Similarly, this agreed with the report of Fadare et al. (2012), who indicated that heat stress suppressed the immune status of sheep that were more susceptible to thermal stress in the hot-humid tropics. The finding further demonstrates that the Red Sokoto kids were better adapted to the northern Guinea savanna zone of Nigeria than the Sahel kids.

In the current study, lower LYMP was observed during the RAS as compared with the HDS in the Red Sokoto goat kids. In a related study, higher LYMP was reported in Dhofari goats during the summer compared with the winter (AlBusaidi et al., 2008). The comparable level of NEUT in all groups of kids in the current study was similar to that reported in Nubian goats by Abdelatif et al. (2009), but disagreed with that of Temizel et al. (2009), who reported a decrease in NEUT in heat-stressed goat kids.

In agreement with the findings of a previous study in Garfagnina goats (Ribeiro et al., 2015), the current study also reported strong discriminant power in MCV and PCV. This finding indicates that such haematological parameters (MCV $\mathrm{MCHC}, \mathrm{MCH}, \mathrm{PCV}$ and $\mathrm{RBC}$ ) are influenced by the three seasons through thermoregulatory mechanisms that cause different physiological effects, and thus they vary markedly in different seasons. However, both the canonical plot representation and the group membership prediction showed that the CDS imposed distinct effects on haematological variables from those by the HDS and RAS which were similar. This was probably due to the low THI during the CDS and high THI during the HDS and RAS, which may induce cold stress and heat stress, respectively (Habibu et al., 2016b).

\section{Conclusion}

Season significantly influenced haematological variables, with the impact of heat stress during the HDS being more profound in kids of Sahel goats, and in younger and male kids of both breeds. The marked seasonal fluctuations in haematological variables of Sahel kids compared to Red Sokoto kids may indicate that the Red Sokoto goats, which are indigenous to the study area, were better adapted to the seasons. Moreover, the TLC was lower in Sahel goats compared with the Red Sokoto goats during the HDS, indicating a higher susceptibility of Sahel goats to heat stress in the study area. These factors necessitate the need for additional support such as provision of ad libitum drinking water and protective shading to the young kids, and especially the kids of the Sahel goats, during the peak of the HDS. It is suggested that the breeding programme be designed in such a way that the 
hot season coincides with the time when the kids. The influence of season on haematological parameters was more pronounced than those of breed, sex and age, hence the need to consider the environmental conditions in which goats are reared in defining reference intervals of haematological parameters. The higher risk of postnatal period of buck kids needs further investigation so as to know whether there is the need for a special managerial provision for the buck kids during thermal stress.

Author contributions. All authors made essential contributions to all steps of the experimental design and manuscript preparation and also approved the final manuscript. However, special contribution was made by Buhari Habibu, Mohammed Kawu, Hussaina Makun and Tagang Aluwong in designing the work. In particular, Buhari Habibu, Lukman Yaqub and Hussaina Makun carried out the field work. Buhari Habibu, Lukman Yaqub and Hajarah Buhari did the laboratory work and statistical analysis. Buhari Habibu, Lukman Yaqub, Mohammed Kawu and Hajarah Buhari wrote the manuscript.

Competing interests. The authors declare that they have no conflict of interest.

Acknowledgements. The Management of NAPRI, Ahmadu Bello University, Shika, Zaria, granted us the permission to use the institution's animals. The staff of the Small Ruminant Research Programme, NAPRI, and Department of Veterinary Physiology, Ahmadu Bello University, Zaria, gave technical assistance. J. O. Ayo and M. Tauheed assisted in drafting the manuscript.

Edited by: M. Mielenz

Reviewed by: F. Fazio and one anonymous referee

\section{References}

Abdelatif, A.M., Ibrahim, Y. M., and Hassan, M. Y.: Seasonal variation in erythrocytic and leukocytic indices and serum proteins of female Nubian goats, Middle-East J. Sci. Res., 4, 168-174, 2009.

Addass, P. A., Midau, A., and Babale, D. M.: Haemato-biochemical findings of indigenous goats in Mubi Adamawa State, Nigeria, J. Agric. Soc. Sci., 6, 14-16, 2010.

Al-Busaidi, R., Johnson, E. H., and Mahgoub, O.: Seasonal variations of phagocytic response, immunoglobulin G (IgG) and plasma cortisol levels in Dhofari goats, Small Rum. Res., 79, 118-123, 2008.

Al-Haidary, A. A.: Physiological responses of Niamey sheep to heat stress, challenge under semi-arid environments, Int. J. Agric. Biol., 6, 307-309, 2004.

Awemu, E. M., Nwakalor, L. N., and Abubakar, B. Y.: Environmental influences on pre-weaning mortality and reproductive performance of Red Sokoto does, Small Rum. Res., 34, 161-165, 1999.

Banerjee, D., Upadhyay, R. C., Chaudhary, U. B., Kumar, R., Singh, S., Ashutosh, Das, T. K., and De, S.: Seasonal variations in physio-biochemical profiles of Indian goats in the paradigm of hot and cold climate, Biol. Rhythm. Res., 46, 221-236, 2015.

Byers, S. R. and Kramer, J. W.: Schalm's Veterinary Hematology, in: Normal Hematology of Sheep and Goats, edited by: Weiss, D. J. and Wardrop, K. J., 6th Edn., John Wiley \& Sons, Ltd., Iowa, USA, 836-842, 2010.

Dzenda, T., Ayo, J. O., Lakpini, C. A.M., and Adelaiye, A. B.: Diurnal, seasonal and sex influences on respiratory rate of African Giant rats (Cricetomys gambianus, Waterhouse) in a tropical Savannah, Wulfenia J., 22, 475-485, 2015.

Egbe-Nwiyi, T. N., Nwaosu, S. C., and Salami, H. A.: Haematological values of apparently healthy sheep and goats as influenced by age and sex in arid zone of Nigeria, Afr. J. Biomed. Res., 3, $109-115,2000$.

Egwu, G. O., Onyeyili, P. A., Chibuzo, G. A., and Ameh, J. A.: Improved productivity of goats and utilisation of goat milk in Nigeria, Small Rum. Res., 16, 195-201, 1995.

El-Abid, K. E. and Abu Nikhaila, A. M. A.: A Study on Some Factors Affecting Mortality Rates in Sudanese Nubian Kids, Int. J. Dairy Sci., 4, 74-79, 2009.

Fadare, A. O., Peters, S. O., Yakubu, A., Sonibare, A. O., Adeleke, M. A., Ozoje, M. O., and Imumorin, I. G.: Physiological and haematological indices suggest superior heat tolerance of whitecoloured West African Dwarf sheep in the hot humid tropics, Trop. Anim. Health Prod., 45, 157-165, 2012.

Fazio, F., Giangrosso, G., Marafioti, S., Zanghì, E., Arfuso, F., and Piccione, G.: Blood haemogram in ovis aries and capra hyrcus: Effect of storage time, Can. J. Anim. Sci., 96, 32-36, 2016.

Foller, M., Braun, M., Qadri, S. M., Lang, E., Mahmud, H., and Lang, F.: Temperature sensitivity of suicidal erythrocyte death, Eur. J. Clin. Invest., 40, 534-540, 2010.

Gall, C.: Goat breeds of the world, Margraf Publishing, Weikersheim, Germany, 1996.

Giulivi, C., Pacifici, R. E., and Davies, K. J. A.: Exposure of hydrophobic moieties promotes the selective degradation of hydrogen peroxide-modified hemoglobin by the multicatalytic proteinase complex, proteasome, Arch. Biochem. Biophys., 311, 329-341, 1994.

Habibu, B., Kawu, M. U., Makum, H. J., Buhari, H. U., and Hussaini, M.: Breed and seasonal variations in erythrocyte osmotic fragility of goat kids raised in semi-arid savannah, Comp. Clin. Pathol., 25, 1309-1312, 2016 .

Habibu, B., Kawu, M. U., Makun, H.J., Aluwong, T., and Yaqub, L. S.: Seasonal variation in body mass index cardinal physiological variables and serum thyroid hormones profiles in relation to susceptibility to thermal stress in goats kids, Small Rum. Res., 145, 20-27, 2016b.

Habibu, B., Kawu, M. U., Makum, H. J., and Aluwong, T.: Influence of seasonal changes on physiological variables, haematology and serum thyroid hormones profile in male Red Sokoto and Sahel goats, J. Appl. Anim. Res., 45, 508-516, 2017.

Haldar, K. C.: Correlation between peripheral melatonin and general immune status of domestic goat, Capra hircus: A seasonal and sex dependent variation, Small Rum. Res., 107, 147-156, 2012.

Hamzaoui, S., Salama, A. A. K., Albanell, E., Such, X., and Caja, G.: Physiological responses and lactational performances of latelactation dairy goats under heat stress conditions, J. Dairy Sci., 96, 6355-6365, 2013. 
Haque, N., Ludri, A., Hossain, S. A., and Ashutosh, M.: Impact on hematological parameters in young and adult murrah buffaloes exposed to acute heat stress, Buffalo Bulletin, 32, 321-326, 2013.

Hashem, A. L. S.: Effect of Summer Shearing on Thermoregulatory, Hematological and Cortisol Responses in Balady and Damascus Goats in Desert of Sinai, Egypt, World Appl. Sci. J., 30, 521533, 2014.

Igono, M. O. and Aliu, Y. O.: Environmental profile and milk production of Friesian-Zubucrosses in Nigerian Guinea Savannah, Int. J. Biometeorol., 26, 115-120, 1982.

Jain, N. C.: Schalm's Veterinary Hematology, 4th Edn., Lea and Febiger, Philadelphia, USA, 1986.

Mazzullo, G., Rifici, C., Cammarata, F., Caccamo, G., Rizzo, M., and Piccione, G.: Effect of different environmental conditions on some haematological parameters in cows, Ann. Anim. Sci., 14, 947-954, 2014.

McManus, C., Paludo, G. R., Louvandini, H., Gugel, R., Sasaki, C. B. L., and Paiva, S. R.: Heat tolerance in Brazilian sheep: physiological and blood parameters, Trop. Anim. Health Prod., 41, 95-101, 2009.

Moore, T., Sorokulova, I., Pustovyy, O., Globa, L., and Vodyanoy, V.: Microscopic evaluation of vesicles shed by rat erythrocytes at elevated temperatures, J. Therm. Biol., 38, 487-492, 2013.

Nicholson, S. E.: Sahel, West Africa, in: Encyclopaedia of Experimental Biology, Vol. 3, Academic Press Inc., USA, 1995.

Nowak, R., Portej, R. H., Levy, F., Orgeur, P., and Schaal, B.: Role of mother-young interactions in the survival of offspring in domestic mammals, Rev. Reprod., 5, 153-163, 2000.

Pacifici, R. E., Kono, Y., and Davies, K. J. A.: Hydrophobicity as the signal for selective degradationon of hydroxyl radical-modified hemoglobin by the multicatalytic proteinase complex, proteasome, J. Biol. Chem., 268, 15405-15411, 1993.

Piccione, G., Monteverde, V., Rizzo, M., Vazzana, I., Assenza, A., Zumbo, A., and Niutta, P. P.: Haematological parameters in Italian goats: comparison between girgentana and aspromontana breeds, J. Appl. Anim. Res., 42, 434-439, 2014.

Piccione, G., Borruso, M., Fazio, F., Giannetto, C., and Caola, G.: Physiological parameters in lambs during the first 30 days postpartum, Small Rum. Res., 72, 57-60, 2007.

Ravagnolo, O., Misztal, I., and Hoogenboom, G.: Genetic component of heat stress in dairy cattle, development of heat index function, J. Dairy Sci., 83, 2120-2125, 2000.

Ribeiro, N. L., Pimenta Filho, E. C., Arandas, J. K. G., Ribeirob, M. N., Saraiva, E. P., Bozzi, R., and Costa, R. G.: Multivariate characterization of the adaptive profile in Brazilian and Italian goat population, Small Rum. Res., 123, 232-237, 2015.

Saddiqi, H. A., Nisa, M., Mukhtar, N., Shahzad, M. A., Jabbar, A., and Sarwar, M.: Documentation of physiological parameters and blood profile in newly born Kajli lambs, Asian-Aust. J. Anim. Sci., 24, 912-918, 2011.
Santucci, P. M., Branca, A., Napoleone, M., Bouche, R., Aumont, G., Poisot, F., and Alexandre, G.: Body condition scoring of goats in extensive conditions. Goat nutrition, edited by: MorandFehr, P., EAAP Publication, Pudoc III, Wageningen, 240-256, http://prodinra.inra.fr/record/92203 (last access: 1 March 2017), 1991.

Sawalha, R. M., Conington, J., Brotherstone, S., and Villanueva, B.: Analyses of lamb survival of Scottish Blackface sheep, Animal, 1, 151-157, 2007.

Sejian, V., Indu, S., and Naqvi, S. M. K.: Impact of short term exposure to different environmental temperature on the blood biochemical and endocrine responses of Malpura ewes under semiarid tropical environment, Indian J. Anim. Sci., 83, 1155-1160, 2013.

Sejian, V., Singh, A. K., Sahoo, A., and Naqvi, S. M. K.: Effect of mineral mixture and antioxidant supplementation on growth, reproductive performance and adaptive capability of Malpura ewes subjected to heat stress, J. Anim. Physiol. Anim. Nutr., 98, 7283, 2014.

Singh, K. M., Singh, S., Ganguly, I., Ganguly, A., Nachiappan, R. K., Chopra, A., and Narula, H. K.: Evaluation of Indian sheep breeds of arid zone under heat stress condition, Small Rum. Res., 141, 113-117, 2016.

Srikandakumar, A., Johnson, E. H., and Mahgoub, O.: Effect of heat stress on respiratory rate, rectal temperature and blood chemistry in Omani and Australian Merino sheep, Small Rum. Res., 49, 193-198, 2003.

Temizel, E. M., Senturk, S., and Kasap, S.: Clinical, haematological and biochemical findings in Saanen goat kids with naturally occurring heat stroke, Tierarztl. Prax. Großtiere, 37, 236-241, 2009.

Tibbo, M., Jibril, Y., Woldemeskel, M., Dawo, F., Aragaw, K., and Rege, J. E. O.: Factors affecting hematological profiles in three Ethiopian indigenous goat breeds, Int. J. Appl. Res. Vet. Med., 2, 297-305, 2004.

Turkson, P. K. and Sualisu, M.: Risk factors for lamb mortality in Sahelian sheep on a breeding station in Ghana, Trop. Anim. Health Prod., 37, 49-64, 2005.

Turkson, P. K., Antiri, Y. K., and Baffuor-Awuah, O.: Risk factors for kid mortality in West African Dwarf goats under an intensive management system in Ghana, Trop. Anim. Health Prod., 36, 353-364, 2004.

Zumbo, A., Sciano, S., Messina, V., Casella, S., di Rosa, A. R., and Piccione, G.: Haematological profile of messinese goat kids and their dams during the first month post-partum, Anim. Sci. Pap. Rep., 29, 223-230, 2011. 